УДК 634.8:581.1

DOI 10.30679/2219-5335-2019-1-55-68-81

ФОРМИРОВАНИЕ

ОКИСЛИТЕЛЬНОГО СТРЕССА

И АНТИОКСИДАНТНЫЕ РЕАКЦИИ У ВИНОГРАДА ПРИ ОБРАБОТКАХ ИНДУКТОРАМИ ИММУНИТЕТА ${ }^{1}$

\author{
Сундырева Мария Андреевна \\ канд. с.-х. наук \\ научный сотрудник \\ лаборатории физиологии \\ и биохимии растений \\ Ушакова Яна Владимировна \\ канд. биол. наук \\ научный сотрудник \\ ЦКП «Приборно-аналитический» \\ Федеральное государственное \\ бюджетное научное учреждение \\ «Северо-Кавказский федеральньий \\ научный центр садоводства, \\ виноградарства, виноделия», \\ Краснодар, Россия
}

Защитные реакции растений

вырабатываются в ответ на восприятие

стрессового фактора и одним из наиболее

ранних ответов является генерация

растением активных форм кислорода.

Последние вызывают в клетках растений

формирование вторичного стрессового

состояния, активирующего и усиливающего

каскад сигнальных событий.

Это приводит к проявлению у растений

серии биохимических изменений,

которые формируют защитный ответ.

Усиление ряда защитных антистрессовых

реакций возможно за счет применения

Стимулирующих веществ - элиситоров,

к которым относятся компоненты самих

растений, а также химические вещества

патогенов, такие как хитозан и экзогенные

фитогормоны. Цель данного исследования изучение особенностей изменения
UDC 634.8:581.1

DOI 10.30679/2219-5335-2019-1-55-68-81

\section{DEVELOPMENT \\ OF OXIDATIVE STRESS \\ AND ANTIOXIDANT REACTIONS IN GRAPES DURING TREATMENTS BY ELICITORS}

\author{
Sundyreva Maria Andreyevna \\ Cand. Agr. Sci. \\ Research Associate \\ of Laboratory of Physiology \\ and Biochemistry of Plants \\ Ushakova Yana Vladimirovna \\ Cand. Biol. Sci. \\ Research Associate \\ of CCU «Instrumental and Analytical»
}

\section{Federal State Budget}

Scientific Institution

«North Caucasian Federal

Scientific Center of Horticulture,

Viticulture, Wine-making»,

Krasnodar, Russia

Plant defense reaction are produced in response to the perception of the stress factor and one of the earliest responses is the generation of reactive oxygen forms by the plant. This forms cause the formation of a secondary stress state in the plants, which activates and intensifies a cascade of signaling events. This leads to the manifestation in the plants of a series of biochemical changes that form a protective answer. Strengthening a number of protective anti-stress reactions is possible through the use of stimulating substances elicitors, which include the components of the plants themselves, as well as chemicals of pathogens, such as chitosan and exogenous phytohormones. The purpose of this research is to study the peculiarities of the change

\footnotetext{
${ }^{1}$ Работа выполнена при поддержке РФФИ грант № 16-34-60154 мол_а_дк

${ }^{1}$ This work was supported by the RFBR grant No. 16-34-60154 mol_a_dk
} 
антиоксидантного ответа у двух сортов винограда, контрастных по устойчивости к милдью, при обработках индукторами иммунитета различного направления действия. Для эксперимента были выбраны полученные in vitro растения контрастных по устойчивости к милдью сортов винограда Мускат белый (поражаемость 4 балла) и Восторг (поражаемость 1 балл). Использовались неплодоносящие растения, первого года посадки. Изучено влияние индукторов иммунитета на развитие окислительного стресса и антиоксидантных реакций у растений винограда с различной устойчивостью к милдью. Показано, что реакции неустойчивого к милдью сорта Мускат белый проявлялись на некоторые из использованных обработок, в то время как у устойчивого сорта Восторг проявлялись сходные реакции на все виды стимуляции иммунитета. Это может свидетельствовать о большой способности воспринимать различные виды сигналов и быстро согласованно на них реагировать, что не приводит к окислительному повреждению растений.

Ключевые слова: ВИНОГРАД, ИНДУКТОРЫ ИММУНИТЕТА, ОКИСЛИТЕЛЬНЫЙ СТРЕСС, АНТИОКСИДАНТНЫЙ ОТВЕТ in the antioxidant response in two grape varieties, contrasting in resistance to mildew, in the process of treatments with inductors of immunity of different directions of action. For the experiment, in vitro plants of contrasting mildew-resistant grape varieties of Muscat Bely (susceptibility 4 points) and Vostopg (susceptibility 1 point) were selected. The non-bearing plants of the first year planting are used. The effect of immunity inducers the development of oxidative stress and antioxidant reactions in grape plants with different resistance to mildew has been studied. It was shown that the reactions of the Muscat Bely variety unstable to the mildew were manifested in some of the used treatments, while the resistant Vostorg variety showed similar reactions to all types of immunity stimulation. This may indicate a great ability to perceive various types of signals and quickly coordinate them to react, which does not lead to oxidative damage of plants.

Key words: GRAPES, IMMUNITY INDUCTORS, OXIDATIVE STRESS, ANTIOXIDANT RESPONSE

Введение. В настоящее время в виноградарстве применяется большое количество разнообразных пестицидов, которые наносят вред природе и здоровью человека [1], способствуют возникновению штаммов, устойчивых к патогенам [2] и существенно повышают капиталоемкость производства, что делает необходимым использование ресурсосберегающих технологий возделывания. Такие технологии должны основываться на использовании биологических свойств растений. Защитные реакции растений вырабатываются в ответ на восприятие стрессового фактора. Одним из наиболее ранних ответов растения является генерация активных форм кислорода (АФК) [3]. Последние вызывают в клетках растений формирование вторичного стрессового состояния, активирующего и усиливающего каскад сигнальных событий $[4,5]$. 
Плодоводство и виноградарство Юга России № 55(01), 2019 г.

Это приводит к проявлению серии биохимических изменений у растений, приводящих к защитному ответу $[6,7]$. Усиление ряда защитных антистрессовых реакций возможно за счет применения стимулирующих веществ - элиситоров, к которым относятся компоненты самих растений, химические вещества патогенов, такие как хитозан, экзогенные фитогормоны $[8,9]$.

Цель исследования - изучение особенностей изменения антиоксидантного ответа у двух сортов винограда, контрастных по устойчивости к милдью, при обработках индукторами иммунитета различного направления действия.

Объекты и методы исследований. Для эксперимента использовали полученные in vitro растения контрастных по устойчивости к милдью сортов винограда Мускат белый (поражаемость 4 балла) и Восторг (поражаемость 1 балл), не плодоносящие, первого года посадки.

Растения выращивались в горшках при 16-часовом световом дне в гроутентах GrowLab (Германия), полив оптимальный. Эксперименты проводились на зрелых интактных листьях, взятых с 16-недельных растений. Листья помещали в чашки Петри с влажной фильтровальной бумагой и на каждый лист наносили по 5 капель (по 20 мкл) соответствующего раствоpa: салициловая кислота в концентрации 0,5мM (SA); метилжасмонат в концентрации 5мМ (МеЈа); хитозан в концентрации 300 мкг/мл (Хит) и комбинации этих веществ.

Контрольный вариант для оценки воздействия салициловой кислоты был обработан водой; 0,1% уксусной кислотой для оценки воздействия хитозана и 0,1 \% этанолом для оценки воздействия метилжасмоната. Отборы осуществлялись через 24, 48 и 72 часа после обработки растений индукторами иммунитета.

Оценку уровня перекисного окисления липидов (ПОЛ) проводили по изменению оптической плотности раствора при реакции малонового диальдегида (МДА) с тиобарбитуровой кислотой (ТБК) [10]. 
Для проведения анализов методом капиллярного электрофореза подготавливали экстракты следующим образом: 0,1 г растертого в жидком азоте образца заливали 1 мл 96 \% спирта и экстрагировали в течение суток при $+4{ }^{\circ} \mathrm{C}$. Затем к образцу добавляли 1 мл деионизованной воды.

После этого образцы центрифугировали при 16000 g 10 минут и комнатной температуре. Супернатант использовали для проведения капиллярного электрофореза. Анализ содержания фенольных соединений, аскорбиновой кислоты, катионов, аминокислот проводили на приборе Капель 104 РТ (Люмэкс, Россия). Расчет концентрации метаболитов производился с помощью программного обеспечения Люмэкс [11]. Белок для определения активности антиоксидантных ферментов экстрагировали из растертых в жидком азоте тканей листа винограда. Определение активности пероксидазы проводили по методу А.Н. Бояркина [12].

Все изучаемые параметры рассчитывались относительно контроля, в графиках и таблицах для наглядности приведен коэффициент, рассчитанный как частное от деления показателей опытного на показатели контрольного варианта.

Обсуждение результатов. Содержание МДА, косвенно характеризующего накопление активных форм кислорода и развитие окислительного стресса, существенно отличалось у растений винограда сорта Восторг и сорта Мускат белый. В сравнении с контролем изменения у сорта Восторг были менее значительными, чем у Муската белого. Салициловая кислота, метилжасмонат и их сочетание приводили к небольшому повышению содержания МДА в листьях обоих сортов винограда через 24 часа после обработки, однако в последующем у сорта Восторг изменения содержания МДА в листьях относительно контроля были существенно меньше, чем таковое у сорта Мускат белый. У сорта Восторг наибольшее повышение содержания МДА в листьях было выявлено через 24 часа после обработки SA, Хит+MeJa, а у Му- 
ската белого окислительное состояние развивалось наиболее интенсивно через 48-72 часа после обработки. Наибольшую реакцию у последнего сорта вызвала обработка МеЈа и сочетаниями индукторов иммунитета (рис. 1).

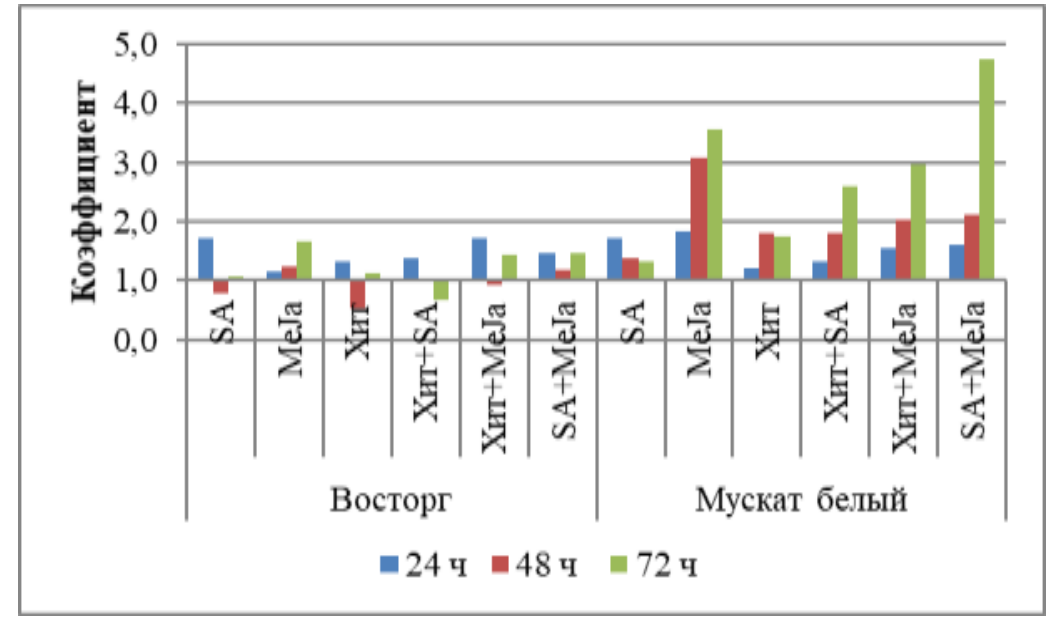

Рис.1. Содержание МДА в листьях винограда при обработках индукторами иммунитета относительно контроля

Содержание свободного кальция в листьях может служить маркером развития стресса у растений. В наших исследованиях два сорта при обработках индукторами иммунитета существенно отличались по этому параметру. Для сорта Восторг характерно снижение содержания кальция в листьях при большинстве обработок индукторами иммунитета. У сорта Мускат белый происходит резкий всплеск содержания кальция относительно контроля в листьях через 24 часа после обработки. Наибольшее влияние оказала обработка хитозаном и Хит+SA, SA+MeJa (рис. 2).

Аминокислота метионин способна индуцировать выделение перекиси водорода, обладает умеренной фунгитоксичностью, провоцирует экспрессию защитных генов и обладает элиситорной активностью [13]. Сорт Восторг при всех типах обработки, кроме салициловой кислоты, характеризовался значительным повышением содержания метионина. У Муската белого такие процессы менее выражены. Таким образом, можно предположить, что экзогенное индуцирование иммунных реакций у сорта Восторг приводит к запуску дополнительных собственных систем регуляции ответа (рис. 3). 


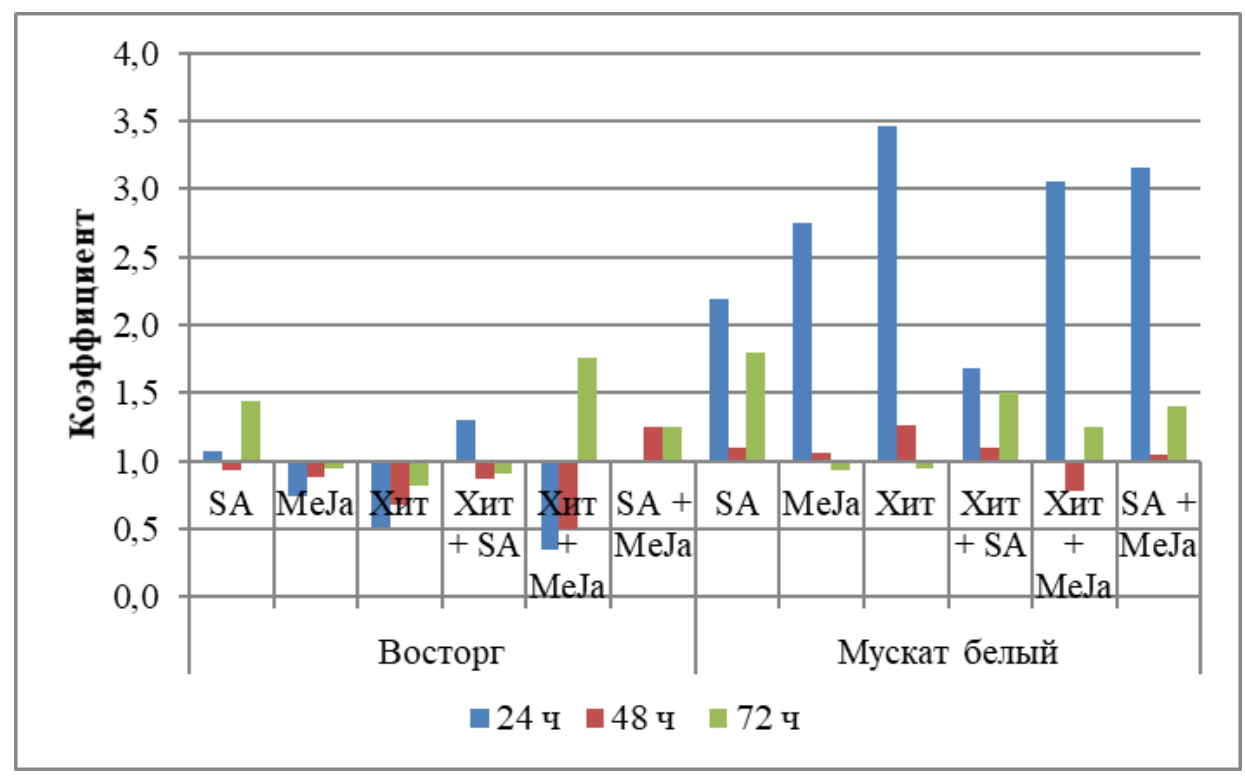

Рис. 2. Содержание свободного кальция в листьях винограда при обработках индукторами иммунитета относительно контроля

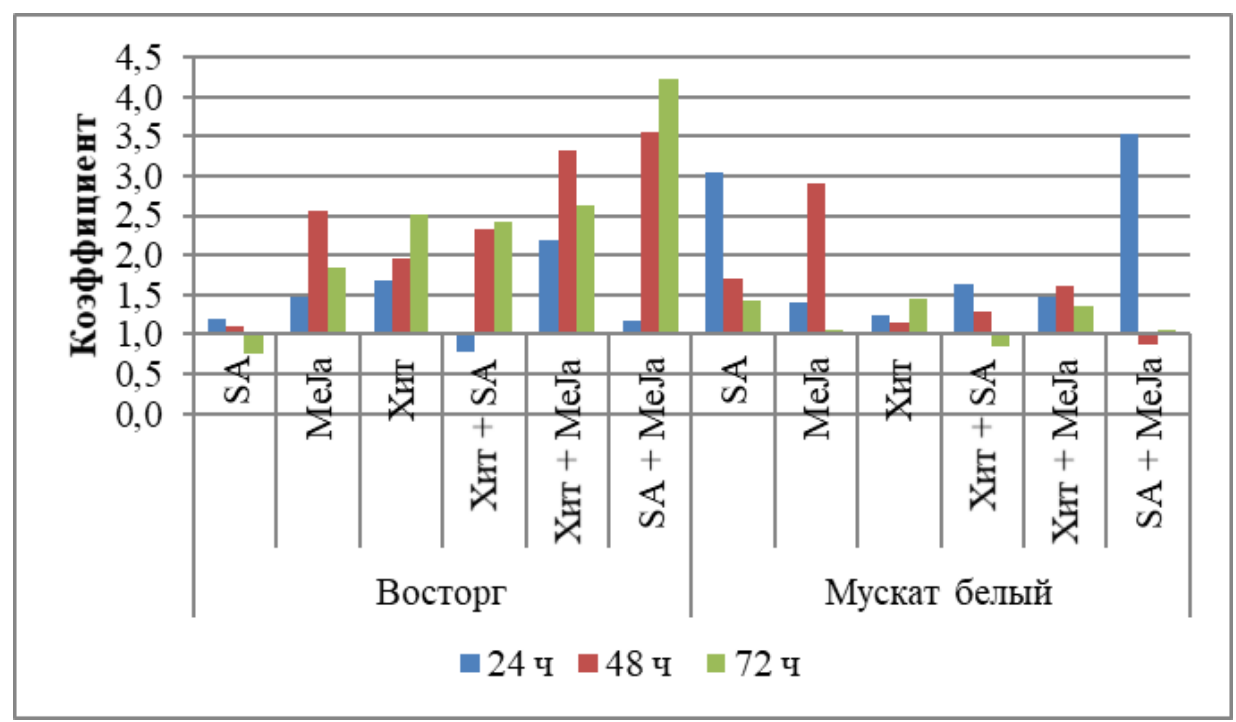

Рис. 3. Содержание метионина в листьях винограда при обработках индукторами иммунитета относительно контроля

Накопление эндогенной салициловой кислоты у сорта Восторг изменялось существенно меньше, чем у сорта Мускат белый. Максимумы содержания салициловой кислоты в листьях обоих сортов были отмечены на вторыетретьи сутки после обработки МеЈа, Хит+Sa (рис. 4). 


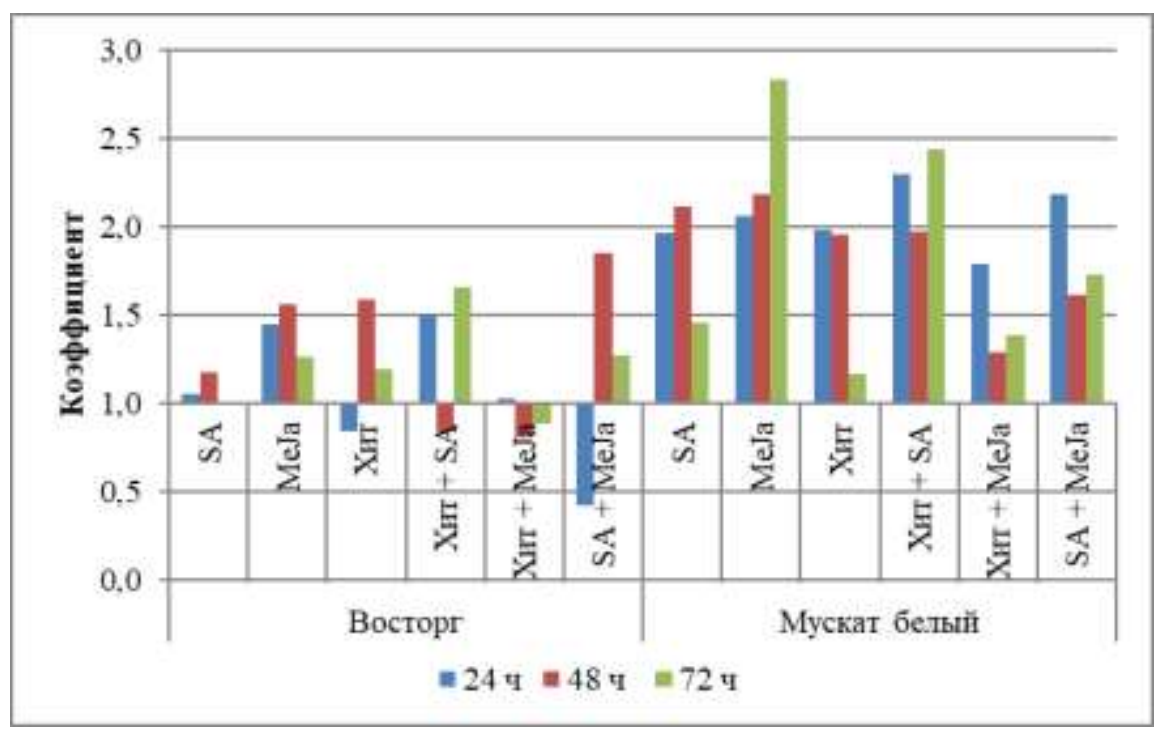

Рис. 4. Содержание салициловой кислоты в листьях винограда при обработках индукторами иммунитета относительно контроля

Через 48 часов после обработки салициловой кислотой и метилжасмонатом приводили к повышению активности пероксидазы. Комбинация салициловой кислоты и метилжасмоната, хитозана и метилжасмоната способствовали увеличению активности пероксидазы через 72 часа после обработки. У сорта Мускат белый все варианты обработок понижали активность пероксидазы, кроме салициловой кислоты, что согласуется с содержанием МДА в листьях (рис. 5).

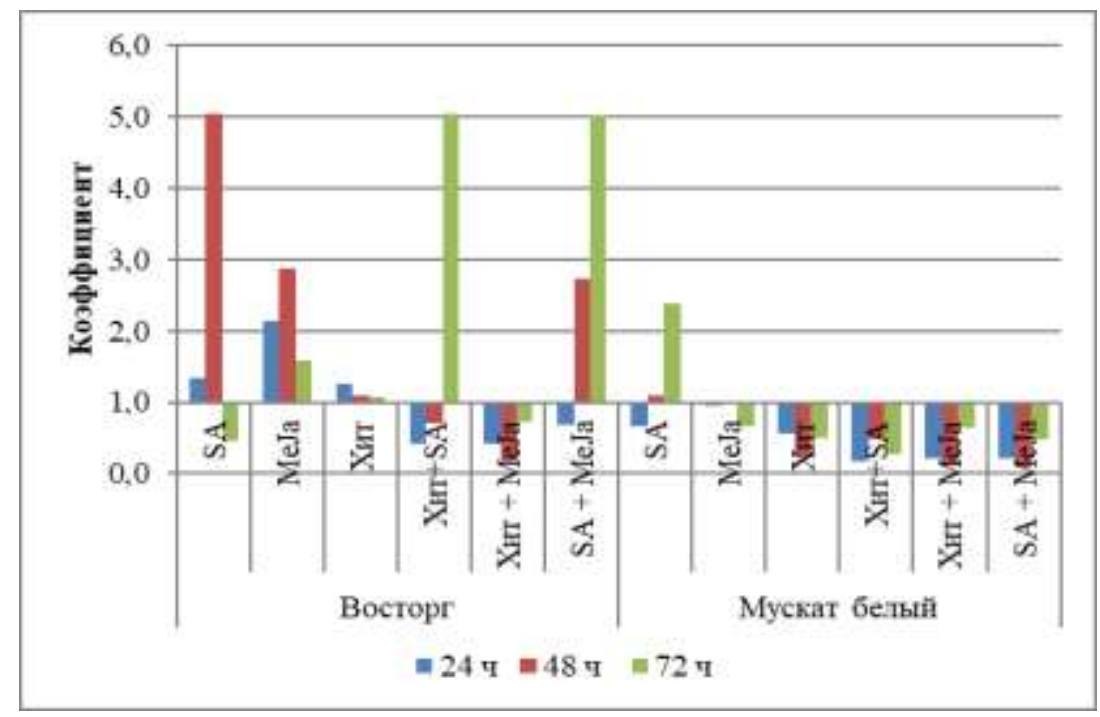

Рис. 5. Активность пероксидазы в листьях винограда при обработках индукторами иммунитета относительно контроля 
Стильбеновые фитоалексины, в том числе и ресвератрол, являются одними из наиболее эффективных метаболитов в защите растений от окислительного стресса. Продукты окисления стильбенов являются важными антимикробными метаболитами [14].

Анализ изменения содержания ресвератрола при каждом варианте обработок метилжасмонатом и его сочетанием с хитозаном и салициловой кислотой приводил к его длительному накоплению в течение анализируемого периода у сорта Восторг. Для сорта Мускат белый характерно повышение содержания ресвератрола только в первые сутки после обработок, которое наиболее выражено в варианте с метилжасмонатом (рис. 6).

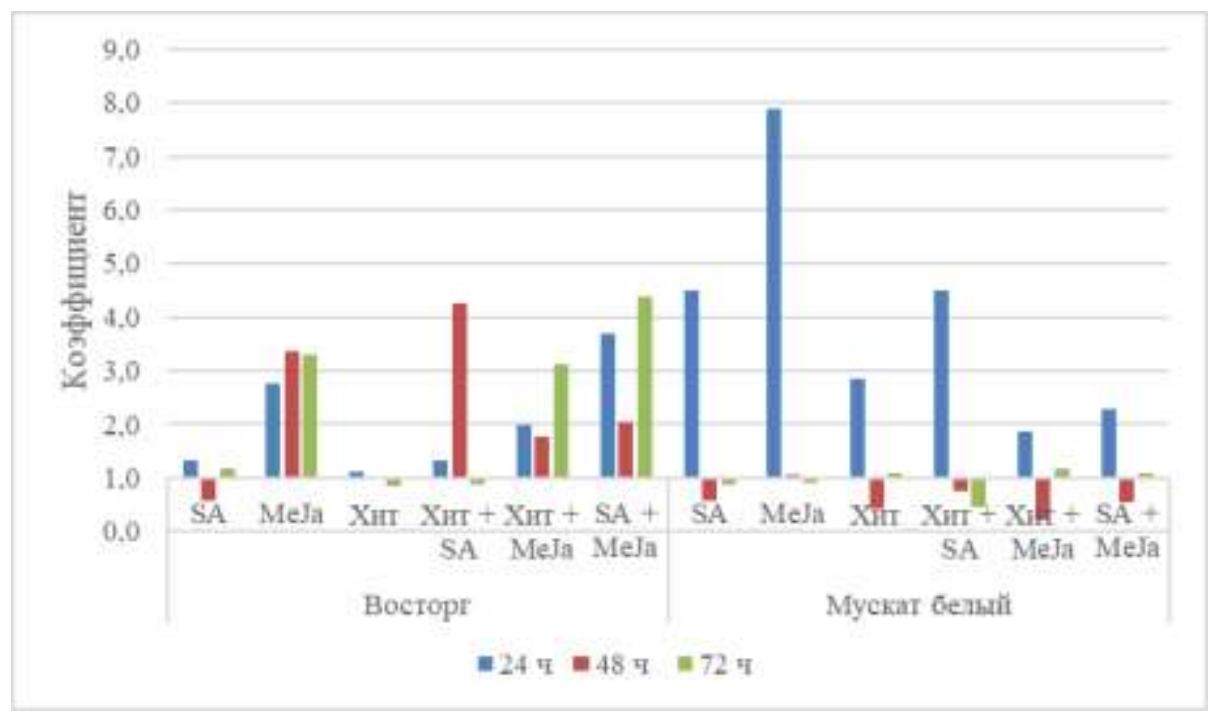

Рис. 6. Содержание ресвератрола в листьях винограда при обработках индукторами иммунитета относительно контроля

Аминокислота пролин, обладающая множественными эффектами в растениях [15], значительно накапливалась в листьях обоих сортов в ответ на обработки индукторами иммунитета через 48-72 часа после обработки. Для сорта Восторг характерно стабильное повышение содержания пролина во всех вариантах опыта. Максимальное его содержание отмечено при обработке МеЈа. У сорта Мускат белый повышение содержания пролина происходило при обработках сочетаниями индукторов иммунитета (рис. 7). 


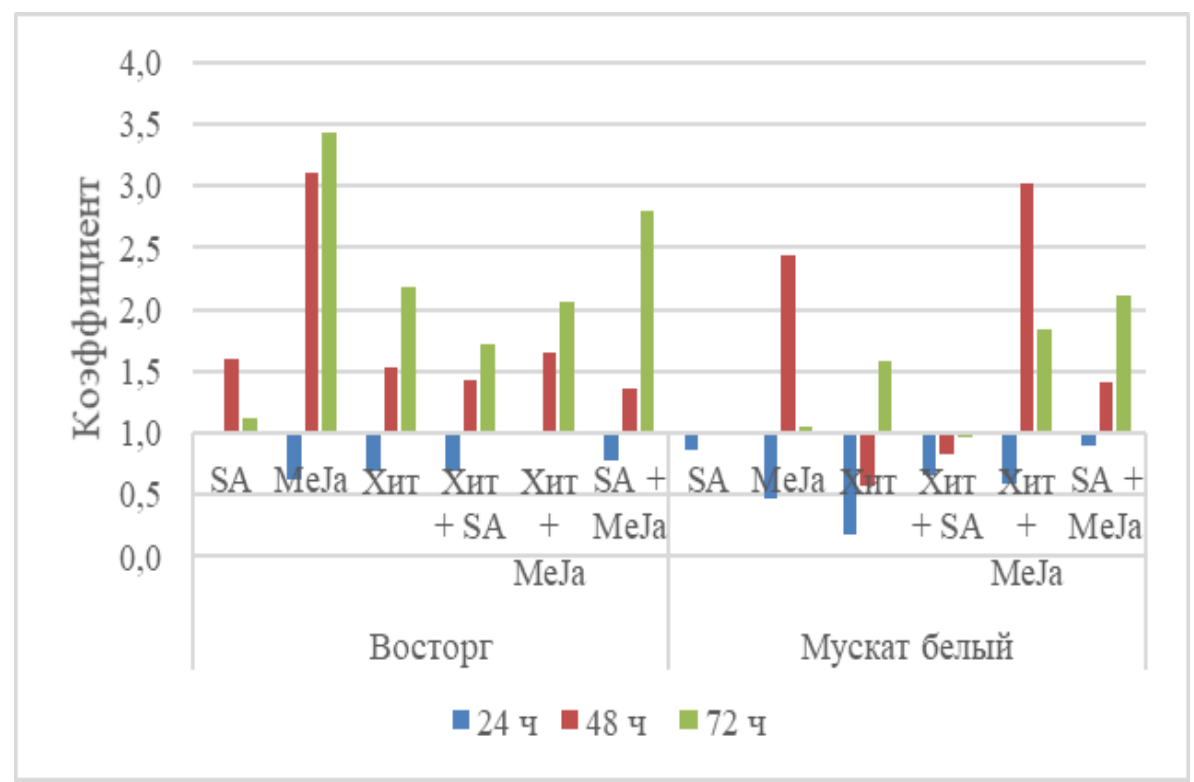

Рис. 7. Содержание пролина в листьях винограда при обработках индукторами иммунитета относительно контроля

Аскорбиновая кислота - один из ключевых элементов аскорбатглутатионового цикла, осуществляющего детоксикацию АФК. Во всех вариантах эксперимента у сорта Восторг происходило снижение содержания этого метаболита в листьях относительно контроля, а в листьях сорта Мускат белый, наоборот, достигая максимума через 72 часа после обработки (рис. 8).

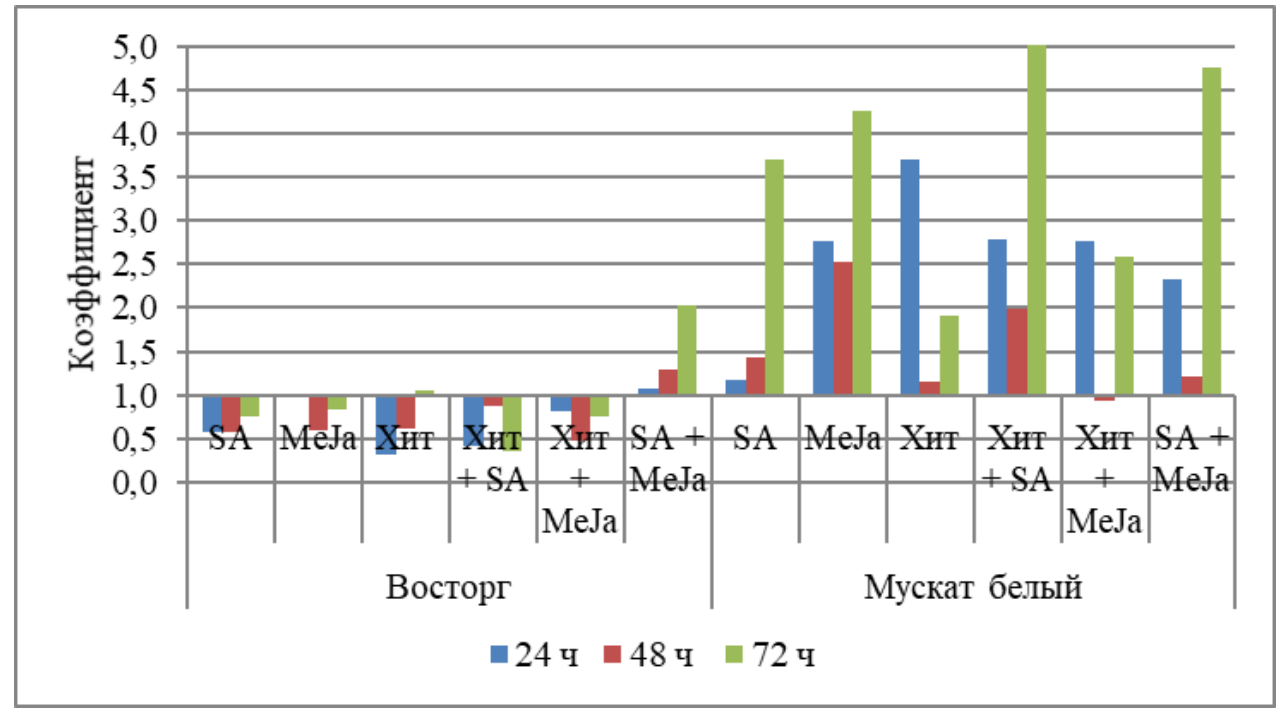

Рис. 8. Содержание аскорбиновой кислоты в листьях винограда при обработках индукторами иммунитета относительно контроля 
Плодоводство и виноградарство Юга России № 55(01), 2019 г.

Элиситоры (индукторы иммунитета) инициируют очень быстрое продуцирование активных форм кислорода, которые действуют как сигналы для активации стрессовых реакций. Активные формы кислорода одновременно с важной сигнальной функцией могут повреждать клеточные структуры и макромолекулы. Окислительное повреждение мембранных липидов сопровождается образованием малонового диальдегида. Клетки растений содержат ряд защитных и восстанавливающих систем, которые при нормальных условиях минимизируют возникновение окислительных повреждений.

Для неустойчивого сорта характерно повышение содержания МДА в листьях, обработанных индукторами иммунитета, следовательно, инициация стрессовых реакций приводит к существенной выработке АФК и недостаточности процессов их детоксикации, подтверждением чему служит рост содержания свободного кальция [16].

Эндогенным стимулятором накопления АФК в растениях является фитогормон салициловая кислота [17]. Для неустойчивого к милдью сорта Мускат белый характерно повреждающее действие АФК, что наиболее вероятно связано с существенным накоплением эндогенной салициловой кислоты.

У устойчивого сорта Восторг тенденция обратная. При обработках индукторами иммунитета содержания МДА и кальция изменялось незначительно относительно контроля, следовательно, можно предположить, что стимуляция иммунных реакций у устойчивого сорта не вызывает деструктивных изменений.

Детоксикация формирующихся во время стресса АФК осуществляется антиоксидантной системой, включающей ряд антиоксидантных ферментов, а также аскорбат-глутатионовый цикл. Пероксидазы являются наиболее распространенными антиоксидантными ферментами в растениях.

В детоксикации АФК в клетках водорослей, риса, подвергнутых воздействию тяжелых металлов $[18,19]$ участвует аминокислота пролин. Обра- 
Плодоводство и виноградарство Юга России № 55(01), 2019 г.

ботка растительного материала пролином снижала содержание перекиси водорода и МДА в клетках виноградного растения [20].

В листьях сорта Мускат белый во всех вариантах опытах происходило снижение активности пероксидазы, причиной чему может быть ингибирующее действие салициловой кислоты [17], накапливающейся в листьях в ответ на обработку индукторами иммунитета.

Ослабление пероксидазной активности может быть причиной роста содержания МДА в листьях. Подтверждением данному предположению может служить выраженный рост содержания аскорбиновой кислоты, являющейся одним из субстратов для пероксидаз.

Тенденция изменения содержания других веществ, обладающих антиоксидантной активностью, - пролина и ресвератрола - у неустойчивого сорта Мускат белый также подтверждает усиление стрессового состояния этого сорта при обработках индукторами иммунитета. Так, содержание ресвератрола возрастало однократно, а пролин накапливался через 48-72 часа после обработок МеЈа, Хит+MeJa, Sa+MeJa.

Устойчивый к грибным заболеваниям сорт винограда Восторг характеризовался увеличением активности пероксидаз вместе со снижением содержания аскорбиновой кислоты и умеренным ростом содержания салицилата. Для этого сорта также характерно увеличение содержания пролина, ресвератрола, метионина во всех вариантах обработок, что может свидетельствовать о большой способности воспринимать различные виды сигналов и быстро согласованно на них реагировать, что не приводит к окислительному повреждению растений.

Bbыводы. Для неустойчивого к милдью сорта винограда Мускат белый характерно накопление АФК и недостаточная их детоксикация, что наиболее вероятно связано с существенным накоплением эндогенной салициловой кислоты при применении индукторов иммунитета. Стимуляция иммунных 
Плодоводство и виноградарство Юга России № 55(01), 2019 г.

реакций у устойчивого сорта Восторг не вызывала деструктивных изменений, а способствовала согласованной активации антиоксидантных систем.

Реакции неустойчивого к милдью сорта Мускат белый проявлялись на некоторые из использованных обработок, в то время как у устойчивого сорта Восторг проявлялись сходные реакции на все виды стимуляции иммунитета. Это может свидетельствовать о большой способности воспринимать различные виды сигналов и быстро согласованно на них реагировать, что не приводит к окислительному повреждению растений.

\section{Литература}

1. Pereira, L.C. A perspective on the potential risks of emerging contaminants to human and environmental health / L.C. Pereira, A.O. de Souza, M.F. Bernardes, [et. al.] // Environ. Sci. Pollut. Res. Int., 2015. - V. 22 (18). - P. 13800-13823.

2. Chen, W.J. At least two origins of fungicide resistance in grapevine downy mildew populations / W.J. Chen, F. Delmotte, S. Richard-Cervera [et. al.] // J. Appl. Environ. Microbiol, 2007. - V. 73 (16). - P. 5162-5172.

3. Mur, L. A. J. A loss of resistance to avirulent bacterial pathogens in tobacco is associated with the attenuation of a salicylic acid- potentiated oxidative burst / L. A. J. Mur, I. R. Brown, R. M. Darby [et. al.] // The plant journal, 2001. - Vol. 23. - P. 609-621

4. Garcia-Brugger, A. Early signaling events induced by elicitors of plant defenses / A. Garcia-Brugger, O. Lamotte, E. Vandelle // Mol. Plant-Microbe Interact., 2006. - V. 19 (7). P. 711-724.

5. Pieterse, C.M. Networking by small molecule hormones in plant immunity / C.M. Pieterse, A. Leon-Reyes, S. Van der Ent, [et. al.] // Nat. Chem. Biol., 2009. - V. 5 (5). P. 308-316.

6. Walters, D.R. Controlling crop diseases using induced resistance: challenges for the future / D.R. Walters, J. Ratsep, N.D. Havis // J. Exp. Bot., 2013. - V. 64 (5). - P. 1263-1280.

7. Boller, T. A renaissance of elicitors: perception of microbe-associated molecular patterns and danger signals by pattern-recognition receptors / T. Boller, G. Felix // Annu. Rev. Plant Biol., 2009. - V. 60. - P. 379-406.

8. Nurnberger, T. Innate immunity in plants and animals: striking similarities and obvious differences / T. Nurnberger, F. Brunner, B. Kemmerling, [et. al.] // Immunol. Rev., 2004. V. 198. - P. 249-266.

9. Wiesel, L. Molecular effects of resistance elicitors from biological origin and their potential for crop protection / L. Wiesel, A.C. Newton, I. Elliott, [et. al.] // Front. Plant Sci., 2014. - V. 5. - 655.

10. Молекулярно-генетические и биохимические методы в современной биологии растений / под ред. Кузнецова Вл.В., Кузнецова В.В., Романова Г.А. - М.: Бином. Лаборатория знаний, 2012. - 487 с

11. Захарова, М.В., Ильина И.А., Лифарь Г.В. Методика определения массовой концентрации аскорбиновой, хлорогеновой и кофейной кислот // Методическое и аналитическое обеспечение исследований по садоводству. - Краснодар: ГНУ СКЗНИИСиВ. 2010. - C. 279-283 
12. Сундырева М.А., Савченко Т.В. Методы экстракции и анализа антиоксидантных ферментов вегетативных органов винограда // Современные инструментально-аналитические методы исследования плодовых культур и винограда. - Краснодар, 2015. - $115 \mathrm{c}$.

13. Boubakri, H. Methionine elicits $\mathrm{H}_{2} \mathrm{O}_{2}$ generation and defense gene expression in grapevine and reduces Plasmopara viticola infection / H. Boubakri, M. A. Wahab, J. Chong [et. al.] // Journal of Plant Physiology, 2013. - V. 170. - P. 1561- 1568

14. Murcia, G. ABA and GA3 regulate the synthesis of primary and secondary metabolites related to alleviation from biotic and abiotic stresses in grapevine / G. Murcia, A. Fontana, M. Pontin, [et. al.] // Phytochemistry, 2017. - V.135. - P. 34-52

15. Szabados, L. Proline: a multifunctional amino acid / L. Szabados, A. Savoure // Cell press, 2009. - P. 89-97

16. Gilroy, S. A tidal wave of signals: calcium and ROS at the forefront of rapid systemic signaling / S. Gilroy, N. Suzuki, G. Miller [et. al.] // Trends in Plant Science, 2014. - V. 19. P. 623-630

17. Durner, J. Inhibition of ascorbate peroxidase by salicylic acid and 2,6-dichloroisonicotinic acid, two inducers of plant defense responses / J. Durner, D.F. Klessig // Proc. Natl. Acad. Sci., 1995. - V. 92. - P. 11312-11316

18. Mehta, S.K. Heavy-metal-induced proline accumulation and its role in ameliorating metal toxicity in Chlorella vulgaris /S.K. Mehta, J.P. Gaur // New Phytol., 1999. - V. 143. P. 253-259

19. Wang, F. Relationship between proline and $\mathrm{Hg}^{2+}$-induced oxidative stress in a tolerant rice mutant / F. Wang, B. Zeng, Z. Sun, [et. al.] // Arch. Environ. Contam. Toxicol. 2009. V. 56. - P. 723-731

20. Ozden, M. Effects of proline on antioxidant system in leaves of grapevine (Vitis vinifera L.) exposed to oxidative stress by $\mathrm{H}_{2} \mathrm{O}_{2}$ /M. Ozden, U. Demirel, A. Kahraman // Scientia Horticulturae, 2009. - V. 119. - P. 163-168

\section{References}

1. Pereira, L.C. A perspective on the potential risks of emerging contaminants to human and environmental health / L.C. Pereira, A.O. de Souza, M.F. Bernardes, [et. al.] // Environ. Sci. Pollut. Res. Int., 2015. - V. 22 (18). - P. 13800-13823.

2. Chen, W.J. At least two origins of fungicide resistance in grapevine downy mildew populations / W.J. Chen, F. Delmotte, S. Richard-Cervera [et. al.] // J. Appl. Environ. Microbiol, 2007. - V. 73 (16). - P. 5162-5172.

3. Mur, L. A. J. A loss of resistance to avirulent bacterial pathogens in tobacco is associated with the attenuation of a salicylic acid- potentiated oxidative burst / L. A. J. Mur, I. R. Brown, R. M. Darby [et. al.] // The plant journal, 2001. - Vol. 23. - P. 609-621

4. Garcia-Brugger, A. Early signaling events induced by elicitors of plant defenses / A. Garcia-Brugger, O. Lamotte, E. Vandelle // Mol. Plant-Microbe Interact., 2006. - V. 19 (7). P. 711-724.

5. Pieterse, C.M. Networking by small molecule hormones in plant immunity / C.M. Pieterse, A. Leon-Reyes, S. Van der Ent, [et. al.] // Nat. Chem. Biol., 2009. - V. 5 (5). P. 308-316.

6. Walters, D.R. Controlling crop diseases using induced resistance: challenges for the future / D.R. Walters, J. Ratsep, N.D. Havis // J. Exp. Bot., 2013. - V. 64 (5). - P. 1263-1280. 
7. Boller, T. A renaissance of elicitors: perception of microbe-associated molecular patterns and danger signals by pattern-recognition receptors / T. Boller, G. Felix // Annu. Rev. Plant Biol., 2009. - V. 60. - P. 379-406.

8. Nurnberger, T. Innate immunity in plants and animals: striking similarities and obvious differences / T. Nurnberger, F. Brunner, B. Kemmerling, [et. al.] // Immunol. Rev., 2004. V. 198. - P. 249-266.

9. Wiesel, L. Molecular effects of resistance elicitors from biological origin and their potential for crop protection / L. Wiesel, A.C. Newton, I. Elliott, [et. al.] // Front. Plant Sci., 2014. -V. 5. - 655 .

10. Molekulyarno-geneticheskie i biohimicheskie metody v sovremennoj biologii rastenij / pod red. Kuznecova Vl.V., Kuznecova V.V., Romanova G.A. - M.: Binom. Laboratoriya znanij, 2012. $-487 \mathrm{~s}$

11. Zaharova, M.V., Il'ina I.A., Lifar' G.V. Metodika opredeleniya massovoj koncentracii askorbinovoj, hlorogenovoj i kofejnoj kislot // Metodicheskoe i analiticheskoe obespechenie issledovanij po sadovodstvu. - Krasnodar: GNU SKZNIISiV. - 2010. - S. 279-283

12. Sundyreva M.A., Savchenko T.V. Metody ekstrakcii i analiza antioksidantnyh fermentov vegetativnyh organov vinograda // Sovremennye instrumental'no-analiticheskie metody issledovaniya plodovyh kul'tur i vinograda. - Krasnodar, 2015. - $115 \mathrm{~s}$.

13. Boubakri, $\mathrm{H}$. Methionine elicits $\mathrm{H}_{2} \mathrm{O}_{2}$ generation and defense gene expression in grapevine and reduces Plasmopara viticola infection / H. Boubakri, M. A. Wahab, J. Chong [et. al.] // Journal of Plant Physiology, 2013. - V. 170. - P. 1561- 1568

14. Murcia, G. ABA and GA3 regulate the synthesis of primary and secondary metabolites related to alleviation from biotic and abiotic stresses in grapevine / G. Murcia, A. Fontana, M. Pontin, [et. al.] // Phytochemistry, 2017. - V.135. - P. 34-52

15. Szabados, L. Proline: a multifunctional amino acid / L. Szabados, A. Savoure // Cell press, 2009. - P. 89-97

16. Gilroy, S. A tidal wave of signals: calcium and ROS at the Forefront of rapid systemic signaling / S. Gilroy, N. Suzuki, G. Miller [et. al.] // Trends in Plant Science, 2014. - V. 19. R. 623-630

17. Durner, J. Inhibition of ascorbate peroxidase by salicylic acid and 2,6-dichloroisonicotinic acid, two inducers of plant defense responses / J. Durner, D.F. Klessig // Proc. Natl. Acad. Sci., 1995. - V. 92. - R. 11312-11316

18. Mehta, S.K. Heavy-metal-induced proline accumulation and its role in ameliorating metal toxicity in Chlorella vulgaris /S.K. Mehta, J.P. Gaur // New Phytol., 1999. - V. 143. P. 253-259

19. Wang, F. Relationship between proline and $\mathrm{Hg}^{2+}$-induced oxidative stress in a tolerant rice mutant / F. Wang, B. Zeng, Z. Sun, [et. al.] // Arch. Environ. Contam. Toxicol. 2009. V. 56. - P. 723-731

20. Ozden, M. Effects of proline on antioxidant system in leaves of grapevine (Vitis vinifera L.) exposed to oxidative stress by $\mathrm{H} 2 \mathrm{O} 2$ /M. Ozden, U. Demirel, A. Kahraman // Scientia Horticulturae, 2009. - V. 119. - P. 163-168 